\title{
TOESPRAAK BY GELEENTHEID VAN 'N GRADEPLEGTIGHEID VAN DIE PU VIR CHO OP 27 APRIL 1990
}

G.C. Velthuysen

Ek het pas teruggekeer van ' $n$ besoek aan Europa. Dáár is dinge aan die gebeur ... Daar is 'n opgewondenheid en tinteling - 'n verwagting en toekomsoptimisme wat die oë laat vonkel - maar tog ook 'n bietjie hart-vashou en onsekerheid ... Want die mense van Europa besef nog nie die volle omvang en betekenis van wat hulle die afgelope maande beleef nie. Trouens, ek dink dat hulle nie eers werklik weet wát aan die plaasvind is nie.

Maar hulle weet dat dit iets groots is ...

Hulle besef dat hulle midde in 'n revolusie is; soos een van hulle vir my gesê het: die grootste sedert die Franse revolusie - en in sommige opsigte selfs groter.

Self dink ek dat Europa tans die voltooiing van dáárdie revolusie beleef. Wat daar aan die gebeur is, is dat waardes wat teen die einde van die $18 \mathrm{de}$ eeu die revolusie in Frankryk ontketen het, besig is om die agtergeblewe dele van Europa te verower - die wat gedurende die 19de en die grootste deel van die 20 ste eeu, vasgevang gebly het in sisteme wat gewissel het van feodalisme tot diktatoriale absolutisme.

$\mathrm{Na} 200$ jaar word die proses voltooi. Ná 200 jaar - ná onvoorstelbaar veel lyding, voortdurende teleurstelling en skynbare mislukking, is die idee van die demokrasie, van die vryheid en waardigheid van die mens, besig om onstuitbaar oor Europa te spoel.

Wat sal die gevolge hiervan wees?

Dit sal die toekoms ons moet leer. Eers ons kinders en kleinkinders sal die perspektief hê wat 'n finale beoordeling moontlik maak. Ons kan egter een ding sê: soos 1789, het 1989 bewys dat die mens se gees nie gebind kan word nie.

- $\quad$ 'n Tydlank wél.

- Maar nie permanent nie ... 
Elke onderdrukkende regering, ideologie en staatsvorm in die geskiedenis van die wêreld het dit probeer doen.

- Hoogstens met tydelike sukses,

want die gees laat nie op hom beslag lê nie.

- Die gees laat hom nie bind nie,

want dit is die draer van idees.

- En'n idee laat hom nie inperk nie.

- Dit kan nie doodgemaak word nie - nie solank as wat daar selfs net één mens gevind kan word in wie dit leef nie.

En selfs al sou dit ook tydelik "sterf" - en stil word, is dit net nodig vir één mens om dit te herontdek - en dit begin 'n hele nuwe lewensloop...

Daarom kan ek sê - kan élke mens sê:

- hulle kan my in boeie slaan, hulle kan my inkerker,

- maar die vlugte van my gees, kan en sal nie aan bande gelê word nie.

- Dit sal, selfs in die gevangenis, selfs onder die verdrukkendste omstandighede, vleuels kry soos die arend - om tot steeds hoër hoogtes te sweef ...

Hier in Suid-Afrika, beleef ons ons eie revolusie. Ons, die Afrikaners. Dit is óns revolusie. Dit het pas begin - en dit is nog nie duidelik wat sy loop sal wees nie. Om van 'n moontlike affloop nog nie eers te praat nie...

Ook in ons geval is dit 'n revolusie van bevryding - wat ons bevry van die gekneldheid waarin ons onsself soveel jare lank gedompel het - 'n gekneldheid wat ons verhinder het om te wees wat ons kán en móét wees...

Hier, tussen ons, is nuwe idees aan die loop. Nuut? Tog ook nie heeltemal so nuut nie. Hulle was maar altyd daar. Binne die raamwerk van die universiteit en die kerk; binne die konteks van die ondersoekende akademiese denke en die geloof, het hulle maar altyd gelewe ...

Ek dink aan idees soos die onvernietigbare waarde van die mens en die onvervreembare vryheid van sy gees - 'n vryheid van keuse en uitdrukkings, vryheid tot gestaltegewing aan die self en aan die leefwêreld, vryheid om 'n vry mens voor God en die mens te wees. Want hierdie is waardes wat nie net deur die liberaal-humanistiese tradisie gedra en beskerm is nie, maar ook, hoewel met ietwat ánder beklemtoning, deur die Afrikaner se teologiese tradisie - met name deur die Calvinisme. Dit is 'n stelling wat ek graag wil bewys: 
Veels te lank het sommige onder ons die Calvinisme geperverteer deur eensydige beklemtonings en skeefgetrekte aksente. Omdat ons byvoorbeeld politieke probleme met iets soos die konsep van menseregte gehad het, het ons onder andere teologiese argumente soos die volgende gebruik om dit te beveg:

Die mens het nie regte nie. Hy het net pligte, want hy is 'n sondaar. Hy is in opstand teen God. Hy leef net by die grasie Gods; daarom kan hy op niks aanspraak maak nie.

Tot sover is die argument natuurlik geldig en korrek. Origens is die oortuiging dat die mens 'n sondaar is, ook een van die heel sentrale geloofswaarhede. Natuurlik is dit dus so dat hy geen aanspraak voor God het nie. Dit impliseer egter nie eers in die verste verte dat hy nie, in sy verhoudings met ander mense, aansprake het nie - maar dit het ons gepas om so te dink. Dit het ons gepas om te sê dat die ander dankbaar moet wees vir wat ons goeddink om vir hulle te gee - maar dat hulle niks meer moet vra of verwag nie ... omdat hulle in elk geval geen aansprake het nie ... Dít, terwyl ons nie gehuiwer het om allerhande regte vir onsself op te eis nie.

- Terwyl ons vergeet het dat die kernwaarheid van ons geloof juis dít is, dat God hierdie sondaar so waardevol ag, dat Hy Homself in Jesus Christus, ter wille van hom in die dood weggee - sodat dit ondenkbaar word dat mense mekaar onderling kan minag en misbruik.

- Terwyl ons in gebreke gebly het om raak te sien dat die Calvinisme sélf, die evangelie nooit anders as só verstaan het nie en dat sy groot leerboek, die Heidelbergse Kategismus, deur uit te gaan van die vraag na die menslike troos, die mens inderdaad in die sentrum van die evangelie en in die brandpunt van religieuse belangstelling plaas. Tot só 'n mate so, dat die Reformasie al dikwels sélf as 'n stuk humanisme getipeer is.

Die waarhede waarna ek verwys het, was steeds dáar al was hulle by geleentheid versluier en onderdruk ...

- Die waarhede het steeds draers gevind.

- Hulle was steeds implisiet aanwesig in die denke van elke mens wat deur hierdie tradisie gevorm is.

- Hulle het na geleentheid gesoek om uit te breek ...

En nou kom hulle al meer in die oopte - al na gelang dit vir al meer en meer mense duidelik word dat die ou denkmodelle nie meer langer deug nie - dat hulle nie meer bevredigende antwoorde op die huidige problematiek moontlik maak nie.

Hierdie, na die oppervlak kom van hierdie idees, is veelal 'n traumatiese ondervinding. Dit is die trauma wat elkeen ervaar wat 'n verandering van denkmodel beleef ... Dit is verwant aan die ervaring wat elkeen van ons gehad het wat, na korter of langer tyd, 
instemming begin betuig het met wat president De Klerk op 2 Februarie 1990 in die parlement gesê het: aanvanklik was daar skok. Maar dit het plek gemaak vir 'n gevoel van bevryding.

Bevryding? Ja, omdat ons geweet het dat dit onvermydelik is - en die oomblik gevrees het ... Maar, toe die oomblik kom, was ons van dáárdie vrees bevry - en kon ons werklik met die probléém, en nie langer met ons vrees nie, aan die worstel raak.

Hierdie nuwe, dog ook ou idees, plaas ons voor uitdagings. Dit vra van ons 'n algehele heroriëntering van ons denke,

'n herwaardering van ons plek,

- 'n herdink van ons taak en toekoms.

Gegewe die inhoud van die idees, is dit egter onvermydelik dat hierdie idees tot 'n geredeliker aanvaarding van mekaar sal lei. Dit beteken onder andere: groter openheid vir mekaar, groter gemeenskaplikheid. Op sy beurt beteken dit vir óns: groter openheid vir Afrika - en groter openheid na Afrika toe ... Wat mót beteken dat die Afrikaner, van sy vrees bevry, nie tevrede sal wees met 'n steeds kleiner wordende plekkie in die son nie - maar dat hy homself sal verruim; sy grondslag dermate sal uitbrei en verbreed dat die waardes wat hy verteenwoordig, 'n steeds groter wordende persentasie van die mense van die land sal verenig en besiel.

Dit is die idee wat ek graag vandag by $u$ wil plant: 'n Afrikanerdom wat bevry van sy vrees, homself oopmaak vir alle mense wat met hom sou wou identifiseer en sy waardes hulle s'n sou wou maak - en homself sodoende verruim.

So 'n Afrikanerdom word nie kleiner nie. Hy word groter en sterker. Want hy word bymekaar gehou en aanmekaar gesmee deur dinge wat régtig belangrik is - die kulturele en religieuse waardes wat hom in die eerste plek gevorm het. Lank voordat ideologie begin het om te misvorm ...

Ek doen dit graag by hierdie geleentheid - omdat dit moeilik sal wees om 'n plek te vind waar meer van die aanwesiges te make het met die vorming en voortdra van idees, as juis by ' $n$ gradeplegtigheid. Gelukkig is diesulkes - die vormers en draers van idees gelukkig en geseënd. Want as dit so is dat idees die toekoms vorm - en dit is so - is dit juis hulle wat die toekoms in hulle hande het. Geskikter draers van die Afrikanerrevolusie sal daarom nie gevind kan word nie.

Dit gaan wesenlik nie om die voortbestaan van die Afrikaner as sodanig nie. Dit gaan 6́6k daarom - maar nie in die eerste plek nie. Dit gaan om die voortleef van die waardes wat vir die Afrikaner kosbaar is. 
- As dié waardes voortleef - sal hy voortleef,

- As hy sónder hulle voortleef - sal sy voortbestaan volkome sinloos wees.

Die ideaal moet wees dat hierdie waardes so wyd en diep in Afrika ingryp, dat dit Afrika kan red en sterk maak - soos dit met die Afrikaner gedoen het.

'n Afrikanerdom wat homself verruim, maak homself sterker - en beter daartoe in staat om hierdie kosbare dienswerk te verrig. Sy denkers is die mense wat hierdie idee érste moet optel en begin dra. 
